Dhaka Univ. J. Biol. Sci. 25(2): 185-194, 2016 (July)

\title{
AN INSIGHT INTO BACTERIOPHAGES' RESPONSE TO VARIOUS PHYSICAL AND CHEMICAL CONDITIONS: TEMPERATURE, $\mathrm{pH}$, SALTS
}

\author{
Tabassum Tasnim Auroni, Md. Deen Islam, Mst. Salma Khatun, \\ Md. Shifat-E-Monjur, Mahmuda Yasmin, Chowdhury Rafiqul Ahsan \\ AND JAMALUNNESSA* \\ Department of Microbiology, University of Dhaka, Dhaka-1000, Bangladesh
}

Key words: Bacteriophage inactivation

\begin{abstract}
Bacteriophages can survive under unfavorable conditions and their abilities of survivality are highly diversified. The influence of different physical and chemical conditions, such as temperature, $\mathrm{pH}$ and salts on the survivability of coliphages and shigaphages isolated from local clinical sewage samples have been summarized. Temperature at $45^{\circ} \mathrm{C}$ for 30 min caused $53.13 \%$ decrease in the number of coliphages but rather increased the number of shigaphages in present study. Temperature at $56^{\circ} \mathrm{C}$ for 30 min caused 91.41 and $100 \%$ fall in the number of coli- and shigaphages, respectively. $\mathrm{pH} 4$ mediated $96.88 \%$ and $\mathrm{pH} 11$ caused $100 \%$ decline in the number of plaques for coliphages. On the other hand, number of plaques of shigaphages was diminished by $100 \%$ at $\mathrm{pH} 4$ and $91.67 \%$ at $\mathrm{pH} 11 . \mathrm{MgCl}_{2}, \mathrm{MgSO}_{4}$ and $\mathrm{Na}_{2} \mathrm{SO}_{4}$ salt solutions increased the number of coliphage plaques by $287.5,125$ and $37.5 \%$. On the contrary, the decrease in the number of shigaphages was $79.31,10.34$ and $44.83 \%$, respectively through the treatment. The various physical and chemical conditions investigated in this research have affected the test bacteriophages diversely. Temperature while applied at higher level $\left(56^{\circ} \mathrm{C}\right)$ affected the growth of both coliphages and shigaphages. Acidic and alkaline $\mathrm{pH}$ modified coli- and shigaphages' survivality and growth negatively. The three salts in question augmented the growth of isolated coliphages profoundly. However, the same three salts failed to do so for the isolated shigaphages.
\end{abstract}

\section{Introduction}

Bacteriophages are viruses which interact with individual bacterial cell surface components and show specificity for particular bacterial species ${ }^{(1,2)}$, but harmless to human, animals and plants. Bacteriophages represent perhaps the most ubiquitous of all biotic drivers(2-4). They are the most numerous form of life on earth; ten times more numerous than bacteria ${ }^{(5,6)}$. They can be found in all environments where bacteria grow: in the Sahara, hot springs, the North Sea, and polar inland waters ${ }^{(7-10)}$.

*Author for correspondence: <jnessa@du.ac.bd>. 
Bacteriophages were first discovered in 1915 by William Twort, and in 1917 Felix d'Herelle realized that they had the potential to kill bacteria ${ }^{(2)}$. Thereby the opportunity of utilizing bacteriophages in human and veterinary medicine, wastewater treatment as well as in various agricultural settings has been exploited ${ }^{(11,12)}$. Phages can keep their promises to decontaminate carcasses and other raw products, to prevent or reduce bacterial colonization in livestock, to extend the shelf life of perishable man-made foods and to disinfect equipments and contact surfaces ${ }^{(13)}$. The demand for natural and biological tools rather than the usage of chemical preservatives in foodstuff and food processing surfaces has recently been enhanced.

More and more people are dying every year because of the multi drug-resistant strains of bacteria such as methicillin-resistant Staphylococcus aureus (MRSA) and wild strains of Salmonella typhi and E. coli(14). The recent emergence pf antibiotic-resistant pathogenic bacterial strains has motivated researchers to look for means of disease control ${ }^{(15,16)}$. Phages are thus being preferred because, unlike broad spectrum antibiotics, phages are highly specific and do not illicit resistance from untargeted bacterial strains ${ }^{(17)}$. The use of bacteriophages for the treatment of diseases that are potentially life threatening is called phage therapy. Phage therapy has been explored for the treatment of diverse diseases, like diarrhoea, cholera, dysentery on several occasions with promising results ${ }^{(18,19)}$.

Earlier study on phages suggested that the phages have cured $90 \%$ of the chronic suppurative bacterial infections (emphysemas, peritonitis, osteomyelitis etc.) in humans caused by antibiotic resistant pathogen such as Staphylococcus aureus, Pseudomonas aeruginosa, Klebsiella pneumoniae and E. coli(20). Outside the host cell, the phages are almost non living and they always need a host cell for replication and other metabolic processes ${ }^{(20)}$. So there is no side effect of phage therapy on treated hosts. Therefore, researches focused on isolating and understanding phages that could provide an additional tool to tackle the global vulnerability to antimicrobial resistance.

Bacteriophages can also cause great economic losses due to fermentation failure in dairy plants (2I). Hence, physical and chemical treatments of raw material and/or equipment are mandatory to maintain phage levels as low as possible. Phages are difficult to eliminate because they rapidly disseminate in dairy plants(22). As phage infections lead to economic losses in dairy factories, the development of control measures require study of bacteriophages.

Bacteriophages as well as animal viruses can be vulnerable to unfavorable physical and chemical factors, such as low and high temperatures, $\mathrm{pH}$, salinity, and ions. So far, an yone who is going to preserve phages should acquire adequate information about their relevant susceptibilities (23). High bacteriophage resistance for external factors is important for stability of phage preparations. However, this feature is highly 
disadvantageous for research and commercial purposes when maintenance of the structural integrity and particular activities of viral strains become crucial. Inactivation of phages in different environments is multi-factorial. It is known that the variation of one factor that influences phages may change phage sensitivity to others ${ }^{(24)}$.

A better understanding of the complex problem of phage sensitivity to external factors and new data may be useful not only for those interested in pharmaceutical and agricultural applications of phages, but also for others working on preservation of phages ${ }^{(25)}$. The aim of the present work was to isolate coli- and shigaphages from nature, determine their titre and explore their comparative vulnerabilities towards some physical agents such as temperature, $\mathrm{pH}$ and salt solutions.

\section{Materials and Methods}

The prevalence of large populations of pathogenic bacteria existing in close proximity in sewage water makes it a relevant source for the isolation of various bacteriophages ${ }^{(4,34)}$. Thus raw sewage sample was collected from the outer ward unit of an urban based hospital where the whole hospital's sewage effluents were collected and later passed to the municipality drainage system ${ }^{(14)}$. The samples were dark ash in color and had strong odor.

The sewage sample was passed through the Whatman No. 1 filter paper two times to remove most of the suspended debris. Filtrate $(1.5 \mathrm{ml})$ was collected into sterile Eppendorf tube and centrifuged at $12000 \mathrm{rpm}$ for 15 minutes. The supernatant was filtered through $0.22 \mu \mathrm{m}$ syringe filter (Millipore USA) to remove the bacterial population. The final filtrate was collected into a sterile vial containing viruses only.

Two bacterial species (E. coli and Shigella flexneri) were employed to isolate the bacteriophages to be used for the determination of the effect of various chemical treatments on them. Luria-Birtani (LB) medium, (Sigma Chemical Company, St. Louis, $\mathrm{MO}, \mathrm{US})$ was used for the cultivation of the two bacterial population.

Loopful of bacterial culture (E. coli and Shigella flexneri) were inoculated into separate tubes containing LB broth. The inoculated broth was incubated for four hours in a shaking incubator at $37^{\circ} \mathrm{C}$.

Prepared (centrifuged and milipore-filtered) sewage sample $(0.5 \mathrm{ml})$ with $0.5 \mathrm{ml}$ of test chemical (double strength chemical) was used to make the working concentration exact. The mixture was incubated at room temperature for 30 minutes. For control, $0.5 \mathrm{ml}$ of prepared (centrifuged with Hettich Mikro 120 centrifuge machine, membrane filtered) sewage sample was mixed with $0.5 \mathrm{ml}$ of sterilized distilled water in it. This mixture was also incubated at room temperature for 30 minutes. Then $100 \boldsymbol{\mu l}$ of treated sewage sample and $100 \boldsymbol{\mu l}$ of young culture of specific bacteria were added into $5 \mathrm{ml}$ of LB soft agar 
$(0.8 \%)$. After mixing gently by hand, this mixture was poured on LB agar plate and briefly swirled by gentle sidewise movement for even and uniform distribution of the top agar over the LB agar in the Petri dish. The top agar was allowed to be solidified. The same process was done for the control. After incubating the plate at $37^{\circ} \mathrm{C}$ overnight, the cleared zones/plaques on the bacterial lawn were observed. The plaque forming units/ml (pfu/ml) of the supplied treated and untreated sewage sample was counted and calculated for each treatment. The average $\mathrm{pfu} / \mathrm{ml}$ was calculated from duplicate tests for each physical treatment. Comparison between the counts obtained for the treated and untreated sewage sample was done to understand the effect of the treatments on the viability and propagation of the specific bacteriophage that have been tested in the experiment.

Table 1. The treatments performed in this study.

\begin{tabular}{|c|c|c|}
\hline Treatment & Working concentration & Incubation temperature and time \\
\hline Temperature: $45^{\circ} \mathrm{C}$ & Not needed & $30 \mathrm{~min}$ in waterbath \\
\hline Temperature: $56^{\circ} \mathrm{C}$ & Not needed & " \\
\hline $\mathrm{pH} 4.0$ & $\begin{array}{l}50 \boldsymbol{\mu l} \text { of IN HCl solution in } 1.0 \\
\text { ml of processed sewage sample }\end{array}$ & $\begin{array}{l}30 \mathrm{~min} \text { at room temperature on bench } \\
\text { (covered with aluminium foil) }\end{array}$ \\
\hline pH 11.0 & $\begin{array}{l}25 \boldsymbol{\mu l} \text { of } \mathrm{IN} \mathrm{NaOH} \text { solution in } 15 \\
\text { ml of processed sewage sample }\end{array}$ & " \\
\hline $\mathrm{MgCl}_{2}$ & $(1 \mathrm{~mol} / \mathrm{A})$ in $\mathrm{H}_{2} \mathrm{O}$ & $\mathrm{MgCl}_{2}+50^{\circ} \mathrm{C}, 1 \mathrm{hr} 50^{\circ} \mathrm{C}, 1 \mathrm{hr}$ (control) \\
\hline $\mathrm{MgSO}_{4}$ & $(1 \mathrm{mMl} /)$ in $\mathrm{H}_{2} \mathrm{O}$ & $\mathrm{MgSO}_{4}+50^{\circ} \mathrm{C}, 1 \mathrm{hr} 50^{\circ} \mathrm{C}, 1 \mathrm{hr}$ (control) \\
\hline $\mathrm{Na}_{2} \mathrm{SO}_{4}$ & $(1 \mathrm{~mol} /)$ in $\mathrm{H}_{2} \mathrm{O}$ & $\mathrm{Na}_{2} \mathrm{SO}_{4}+50^{\circ} \mathrm{C}, 1 \mathrm{hr} 50^{\circ} \mathrm{C}, 1 \mathrm{hr}$ (control) \\
\hline
\end{tabular}

\section{Results and Discussion}

In recent years considerable attention has been focused on bacteriophages, which are widely distributed in the environment. They play important roles not only in treating systemic and enteric diseases but also in preventing bacterial contamination of food products and packaging. Their surprisingly diverse ability of survival under unfavorable conditions has inspired, scientists to characterize them. In this experiment, the prevalence of large populations of pathogenic bacteria existing in close proximity in sewage water made it a relevant source for the isolation of various bacteriophages. They were found to have bactericidal properties as they largely feed on specific bacteria. Various external physical and chemical factors, such as temperature, acidity, salinity, and ions, determine the occurrence, viability, and storage of bacteriophages. These versatile applicants can inactivate a phage by destabilizing its structural integrity by affecting capsid or envelope, facilitating lipid loss, and/or initiating NA structural deviation ${ }^{(14)}$. A few of these attributes may also positively interfere with the endurance and thus enhance its survival. 
Bacteriophages infecting E. coli and phages specific for S. flexneri sustaining in clinical sewage were isolated in summer (April, 2014) and subsequently were enumerated by host assessment. Most (89\%) members of the isolated phage population were specific for S. flexneri. Only $11 \%$ of the isolated viruses had infected E. coli. Proportion of various bacteriophages in nature varies widely with time and place.

The phages obtained in this experiment were lytic. The development of clear zones of lysis against specific host bacteria using phage lysate indicated that all the phages isolated were lytic phages.

While heat treatment was applied at different degrees, the test coli phages reacted differently. Higher temperature made viruses more vulnerable as they were reduced by $91.41 \%$ at 56 DC compared to $53.13 \%$ decrease at $45^{\circ} \mathrm{C}$ (Fig. 1). Temperature is a crucial factor for bacteriophage survivability(27-30) as it plays a fundamental role in attachment, penetration and multiplication. Thermal treatments produce morphological changes on phage particles. The effects of such treatments were monitored in transmission electron microscopy (27) by Atamer et al. (2010). Release of phage DNA from viral capsids, decomposition of phage into head and tail structures, and aggregation of phage tails were the most frequently seen phenomena, principally for the heat sensitive phage studied. For heat resistant ones, changes in morphology were less evident.

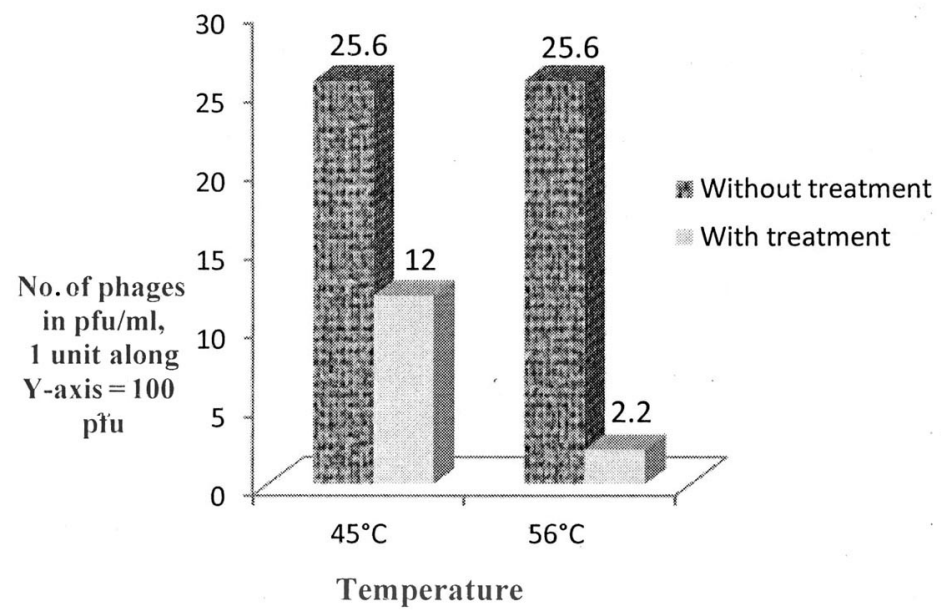

Fig. 1. Susceptibility of isolated coliphages at stated temperature for $30 \mathrm{~min}$.

However, for shigaphages $45^{\circ} \mathrm{C}$ did not have any negative effect on their plaque numbers at all. But $100 \%$ decrease in the number of plaque occurred when the phages were incubated at $56^{\circ} \mathrm{C}$ for 30 minutes (Fig. 2).

Another important factor affecting phage stability was the acidity and alkalinity of the environment. In a previous study, Kerby et al. (1949)(31) suggested that irreversible 
coagulation and precipitation of bacteriophages according to environment might be the factors limiting phage activity. Feng et al. (2003)(32) investigated the survivability of coliphages in water and wastewater with regard to the effects of different $\mathrm{pH}$. In his study, coliphages presented lowest inactivation rate in the range of $\mathrm{pH} 6$ to 8. Langlet et al.(33) showed that hydrogen ion concentration influenced phage aggregation. Their aggregation could be up to $6 \mu \mathrm{m}$ in diameter. Acidity may cause a decline in phage count and may subsequently eliminate aggregates through their adsorptibn on host cell membranes than single virion alone.

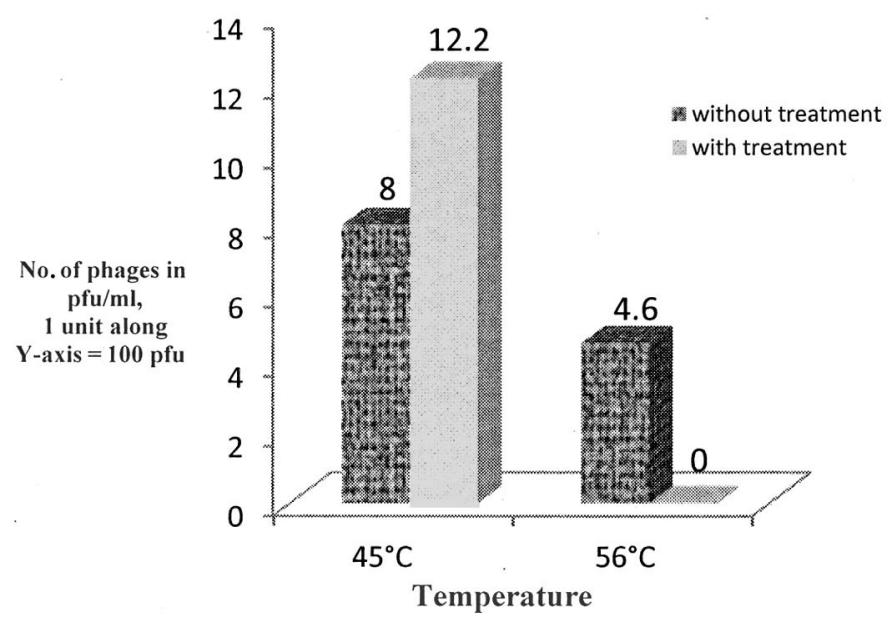

Fig. 2. Response of isolated shigaphages at stated temperature for $30 \mathrm{~min}$.

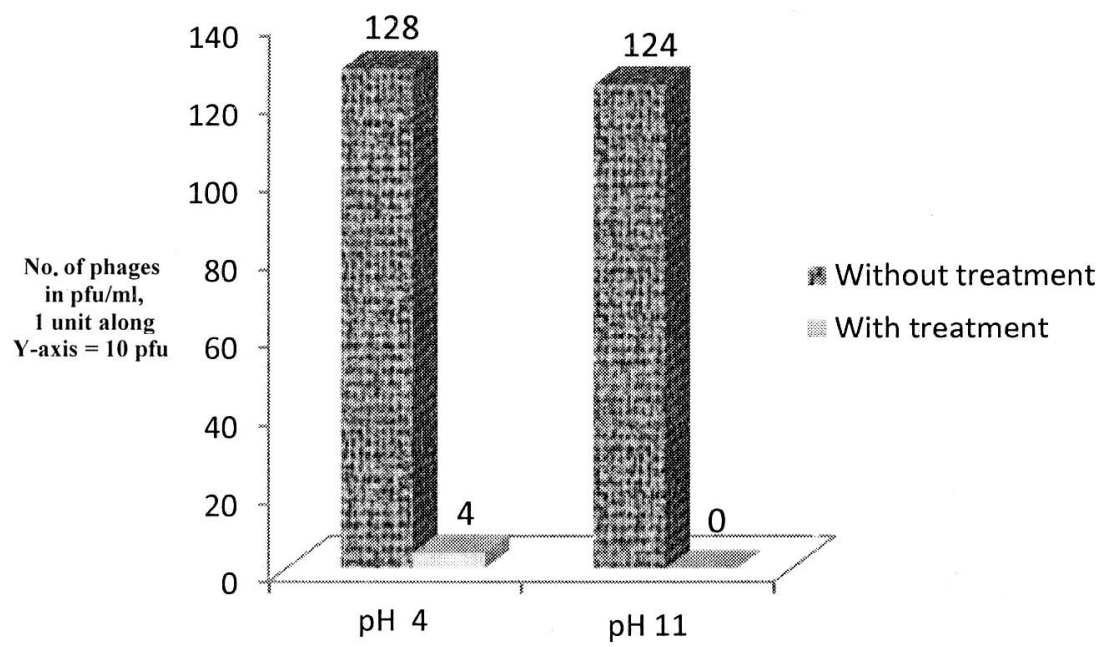

Fig. 3. Vulnerability from isolated coliphages at different $\mathrm{pH}$ exposure. 
pH 4 mediated $96.875 \%$ and $\mathrm{pH} 11$ caused 100\% reduction in the number of plaques for coliphages (Fig. 3). On the other hand, the number of plaques for shigaphages was declined by $100 \%$ at $\mathrm{pH} 4$ and $91.67 \%$ at pH 11 (Fig. 4). So it could be deduced that, acidic environment presented higher inactivation rate to shigaphages than coliphages. On the contrary, alkaline condition provided higher destabilization to coliphages than shigaphages.

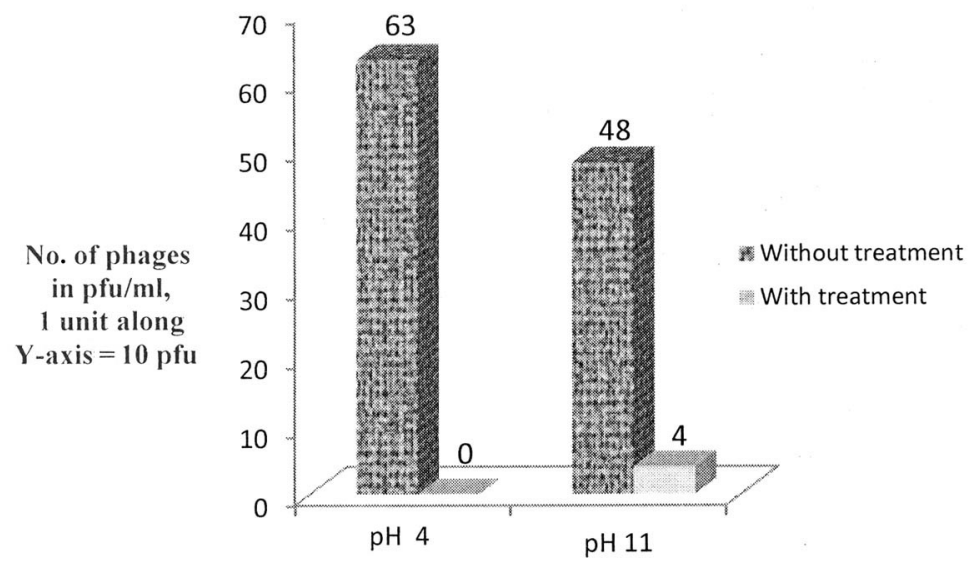

Fig. 4. Survivability of isolated shigaphages at different $\mathrm{pH}$ values.

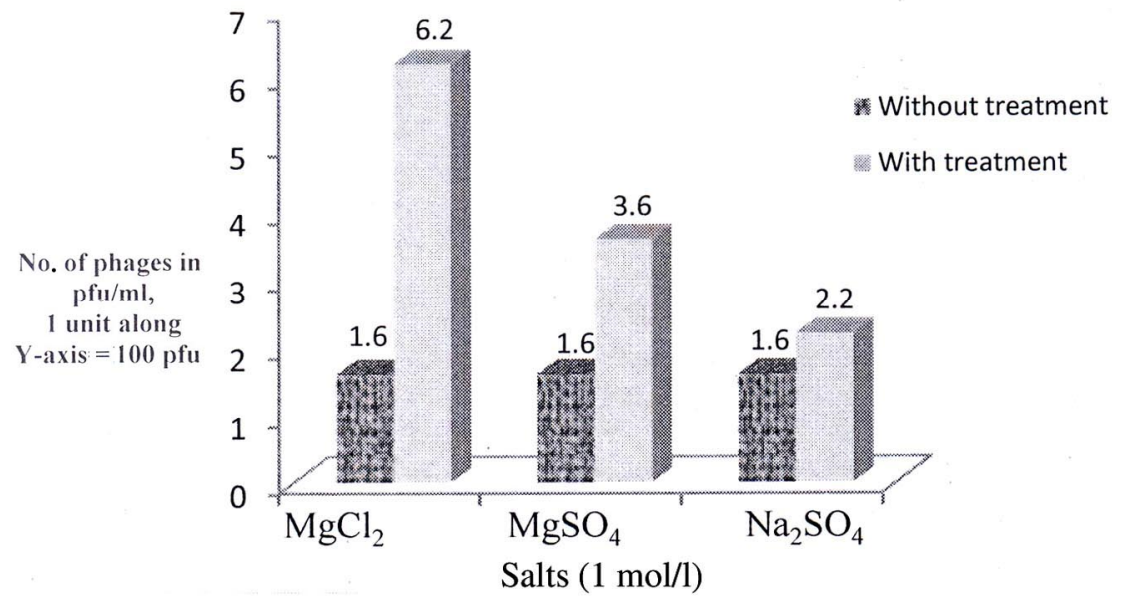

Fig. 5. Effects of various salts on thermal stability of isolated coliphages.

In the present study three inorganic divalent salts $\left(\mathrm{MgCl}_{2}, \mathrm{MgSO}_{4}\right.$ and $\left.\mathrm{Na}_{2} \mathrm{SO}_{4}\right)$ were investigated to understand their degree of influence on the thermal stability of bacteriophages. While treated with each of the three salts, coliphages showed significantly elevated persistence at $50^{\circ} \mathrm{C} . \mathrm{MgCl}_{2}, \mathrm{MgSO}_{4}$ and $\mathrm{Na}_{2} \mathrm{SO}_{4}$ caused the increase 
in viral plaque count by $287.5,125$ and $37.5 \%$ respectively (Fig. 5). However, shigaphages had lost their activity at $50^{\circ} \mathrm{C}$ after an hour long treatment with each of the three test salts. The number of shigaphages was reduced by 79.31, 10.34 and $44.83 \%$ through treatment with $\mathrm{MgCl}_{2}, \mathrm{MgSO}_{4}$ and $\mathrm{Na}_{2} \mathrm{SO}_{4}$, respectively (Fig. 6).

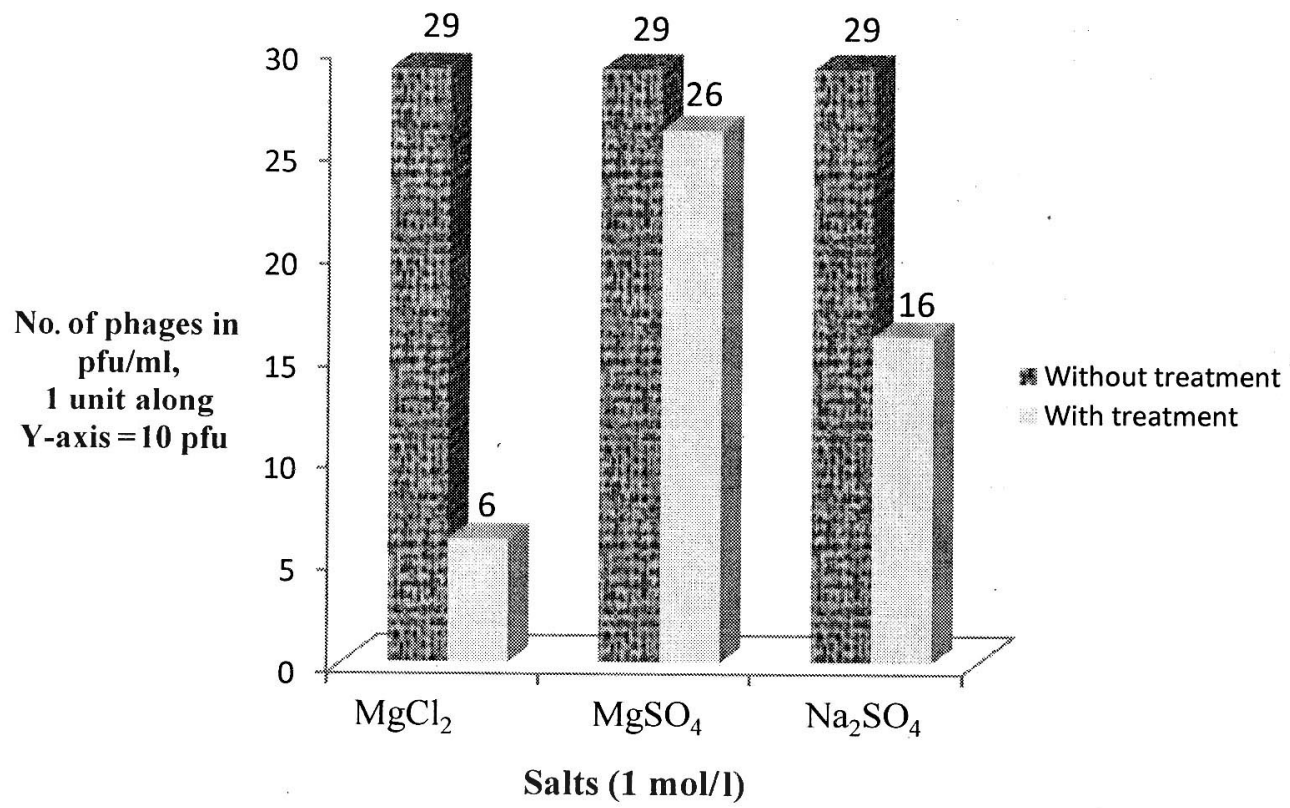

Fig. 6. Effects of various salts on thermal stability of isolated shigaphages.

Viruses are the most diversely structured groups of entities among the microorganisms. The data presented here constitute an important piece of information regarding the variability of sensitivity of bacteriophages to different physical and chemical conditions. The diversity observed among phages to different inactivating and stabilizing conditions is necessary to be assessed prior to using phages and phagederivative products to ensure the maintenance of standard biosafety level ${ }^{(34)}$. Temperature, $\mathrm{pH}$ and salts seem to be very important factors for shifting the count of bacteriophages collected from nature. The results demonstrated here could be applied in generating new data for the pharmaceutical and agricultural industries working on phage survivability and methods of their further preservation.

\section{References}

1. Madigan MT, JM Martinko, PV Dunlap and DP Clark 2009. Microbial growth control. Brock Biology of Microorganisms. 12th ed. pp. 808. Pearson Education Inc. 1301 Sansome Street, San Francisco, CA 94111. 
2. Clokie MRJ, AD Millard, A V Letarov and SHeaphy 2011. Phages in nature. Bacteriophage 1: 31-45.

3. Suttle CA 2005. Viruses in the sea. Nature 437: 356-361.

4. Rodriguez-Valera F, AB Martin-Cuadrado, B Rodriguez-Brito, L Pasic, TF Thingstad, F Rohwer and A Mira 2009. Explaining microbial population genomics through phage predation. Nat. Rev. Micro. 7: 828-836.

5. Hendrix RW 2002. Bacteriophages: evolution of the majority. Theor. Popul. Biol. 61: 471-480.

6. Hanlon GW 2007. Bacteriophages: An appraisal of their role in the treatment of bacterial infections. Int. J. Antimicrob. Agents 30: 118-128.

7. Prigent M, M Leroy, F Confalonieri, M Dutertre and MS Du Bow 2005. A diversity of bacteriophages forms and genomes can be isolated from the surface sands of Sahara Desert. Extremophiles 9: 289-296.

8. Lin L, W Honh, X Ji, J Han, L Huang and Y Wei 2010. Isolation and characterization of an extremely long tail Thermus bacteriophage from Tegchong hot springs in China. J. Basic Microbiol. 50: 452- 456.

9. Breitbart M, L Wegley, S Leeds, T Schoenfeld and F Rohwer 2004. Phage community dynamics in hot springs. Appl. Environ. Microbiol. 70: 1633-1640.

10. Sawstr6m CH, J Lisle, AM Anesio, JC Priscu and J Laybourn-Parry 2008. Bacteriophage in polar inland waters. Extremophiles 12: 167-175.

11. Choi J, SM Kotay and R Goel 2011. Bacteriophage-based biocontrol of biological sludge bulking in wastewater. Bioeng. Bugs. 2(4): 214-7.

12. Dhevagi P and S Anusuya 2013. A novel approach for pathogen reduction in wastewater treatment. J. Environ. Sci. Health 11: 12.

13. Sharma M, JR Patel, WS Conway, S Ferguson and A Sulakvelidze 2009. Effectiveness of bacteriophages in reducing Escherichia coli 0157:H7 on fresh-cut cantaloupes and lettucet. J. Food Proto. 72(7): 1481-1485.

14. Mahadevan MS, D Arijit, B Sourav and S Sandeep 2009. Isolation of host-specific bacteriophages from sewage against human pathogens. Asian J. Biotech. I. 4: 163-170.

15. Karen Ho. 2001. Bacteriophage therapy for bacterial infections: rekindling a memory from the pre-antibiotics era. Perspect. Biol. Med. 44(1): 1-16.

16. Alam M, MZ Akhter, M Yasmin, CR Ahsan and J Nessa 201 I. Local bacteriophage isolates showed anti-Escherichia coli 0157 : H7 potency in an experimental ligated rabbit ileal loop model. Can. J. Microbiol. 57: 408-415.

17. Sulakvelidze A and E Kutter 2005. Bacteriophage Therapy in Humans. Bacteriophages: Biology and Applications.' CRC Press, Boca Rutan FL., ISBN: 0-8493-1336-8, pp: 381-436.

18. Alexander S, A Zemphira and Glenn 2001. Bacteriophage Therapy. Antimicrob Agents Chemother. ASM. 45(3): 649-659.

19. Summers WC 2001. Bacteriophage therapy. Annu. Rev. Microbiol. 55: 437- 451.

20. Carlton RM 1999. Phage therapy: Past history and future prospects. Archivum. Immunol. Therapiae. Expt. 47: 267-274. 
21. Daniela MG, JM Diego, AR Jorge and DLQ Andrea 2011. Review: efficiency of physical and chemical treatments on the inactivation of dairy bacteriophages. Front Microbiol. 2: 282.

22. Neve H, U Krusch and M Teuber 1989. Classification of virulent bacteriophages of S. salivarius spp. thermophilus isolated from yoghurt and Swiss-type cheese. Appl. Microbiol. Biotechnol. 30: 624-629.

23. Ackermann HW, D Tremblay and S Moineau 2004. Long-term bacteriophage preservation. WFCC Newslett. 38: 35-40.

24. Muller-Merbach M, T Rauscher and J Hinrichs 2004. Inactivation of bacteriophages by thermal and high-pressure treatment. Int. Dairy J. 15: 777-784.

25. JOJlczyk E, M Klak, R Miydzybrodzki and A Gorski 201 I. The influence of external factors on bacteriophages-review. Folia Microbiol. 56: 191-200.

26. Sands JA and RA Lowlicht 1976. Temporal origin of viral phospholipids of the enveloped bacteriophage phi 6. Can. J. Microbiol. 22(2): 154-8.

27. Olson MR, RP Axler.and RE Hicks 2004. Effects of freezing and storage temperature on MS2 viability. J. Virol. Meth. 122: 147-152.

28. Nasser A and S Oman 1999. Quantitative assessment of the inactivation of pathogenic and indicator viruses in natural water sources. Water Res. 33: 1748-1752.

29. Yates MV, CP Gerba and LM Kelley 1985. Virus persistence in ground water. Appl. Environ. Microbiol. 31: 778-781.

30. Hurst CJ, CP Gerba and I Cech 1980. Effects of environmental variables and soil characteristics on virus survival in soil. Appl. Environ. Microbiol. 40: 1067-1079.

31. Kerby GP, RA Godwy, ES Dillon, ML Dillon, TZ Csaky, DG Sharp and JW Beard 1949. Purification, $\mathrm{pH}$ stability and sedimentation properties of the T7 bacteriophage of Escherichia coli. J. Immunol. 63: 93-107.

32. Feng YY, SL Ong, JY Hu, XL Tan and WJ Ng 2003. Effects of $\mathrm{pH}$ and temperature on the survival of coliphages MS2 and Qbeta. J. Ind. Microbiol. Biotechnol. 30: 549-552.

33. Langlet J, F Gaboriaud and C Gantzer 2007. Effects of $\mathrm{pH}$ on plaque forming unit counts and aggregation ofMS2 bacteriophage. J. Appl. Microbiol. 103: 1632-1638.

34. Islam MD, TT Auroni, MS Khatun, MS Monjur, M Yasmin, CR Ahsan and J Nessa 2015. Virucidal efficiency of chemical agents: A comparative analysis. Bangladesh J. Microbiol. 31: 47-52. 